\title{
ジュネーブで開催された照射食品の受容，管理，貿易に関する 国際会議について
}

日本食品照射研究協議会事務局

\section{International Conference on the Acceptance, Control of and Trade in Irradiated Food}

Japanese Research Association for Food Irradiation

1988年12月12日(月)から16日(金の 5 日間, スイスのジュネーブで「照射食品の受容, 管理, 貿易に関する国際会 議」が開催された。この会議はIAEA，FAO，WHO，ITC-UNCTAD/GATT の共催によるものであり，57ケ国お よび14の国際機関や非政府機関からの科学者, 行政官, 消費者など200名以上が参加した。この会議では1988年 12月16日に最終文書が総意で採択された。最終文書は, 法的な拘束力を持たないが, 政府レベルの協力, 消費者 の態度, 工程管理, 貿易を含む広範囲にわたる項目についての合意を反映したものであり, 食品照射の今後の国 際的な発展に重要な影響を及ほすものである。

最終合意文書の結論と勧告は以下のとおりである。

\section{桔熺}

・食品照射は, 食品, 特に固体食品の病原菌污染を低減させて食品由来の病気を減少させる可能性を秘めている。

・食品照射は, 農産物のポストハーベストロスを隇少させて消費者に多くの多様な食品を提供することを可能に する。さらに，食品照射はある種の農産物の植物防疫手段として有効であり，農産物の国際間貿易を促進する。

・照射食品に関する国際一般規格および食品照射の実施に関する国際規範に従った，政府当局による規制・管理 の実施が食品照射の導入の前提となる。食品照射はGMP の代替として使用すべきでない。

・食品照射の管理のための各国の規制を国際的に認められた規格に基づいて調和することにより，照射食品の国 際間貿易が促進されるであろう。

・消費者の受容が食品照射の成功にとっての重要な因子であり, そのためには情報の提供が必要である。

\section{初告}

・食品照射を適用することが有効であると思われる食品に対しては, 国民の健康のために食品照射技術を利用す ることを考虑すべきである。

・食品照射が農産物のポストハーベストロスを隇少したり植物防疫の手段として有効である場合には, 食品照射 を利用することを考虑すべきである。

・食品照射の実施および照射食品の販売の前提条件として, 各国政府は食品の照射および照射食品の販売を管理 
するための規制を策定すべきである。とくに照射施設の登録, 許可, 管理, 検査, 照射食品に関する記録と表 示，監督官のトレーニング，GMP の導入などに関する事項を，策定する规制に盛り込むべきである。

・食品照射を管理するための規制を策定する時には，その規制が照射食品に関する国際一般規格および食品照射 の実施に関する国際規範に盛り込まれた国際的に同意された原則と一致するようにすべきである。食品照射の 実施中は, 各国および国際的な规格で定められた線量測定を行って, 正当な食品照射が実施されていることを 示す証拠とすべきである。

・各国政府は，照射施設を離れても行政による照射食品の管理が行えるように，照射食品の検知技術の開発のた めの研究を推進すべきである。このことにより, 照射食品の国際間貿易が促進され, 消費者が照射食品の全体 の管理システムに対して信頼するようになる。

・国際貿易に供される照射食品の表示は，食品規格委員会により採択された原則と一致したものでなければなら ない。

・各国政府は，食品照射施設の設計および運転が，人間の健康，安全および環境の保護のために国際的に合意さ れた基準に合致した規制に従うようにすべきである。

・各国政府,とくに食品照射を許可しょうとしている政府は,食品照射について明暸で適切な情報を提供するよう にすべきである。その際，消費者団体を含むあらゆる関心を有している団体の参加を得るようにすべきである。

この会議には国際消費者連盟（IOCU）がオブザーバーとして参加し，照射食品に対する質問状を提出した。 これに対して，WHO は回答を作成した。

IOCU の提出した質問及びその回答は以下のとおりである。

\section{IOCU の提示した疑問}

照射食品の安全性に関する未解決の疑問

照射食品の安全性及び栄養に関して未解決な問題があり，さらに，食品照射技術の管理に関しても問題がある。 このことはある種の食品の貿易において食品照射が乱用される可能性を示している。

このような問題は，食品照射か広く消費者に受け入れられる前に，そして照射食品がさらに利用されたり開発 される前に，解決する必要がある。

WHO に対して, 食品照射に係わる安全性, 栄養, 国民の健康に関する問題すべてについて文献を完全に引用 した分かりやすいレポートを作成することを要望する。なお, レポートの作成に当たっては, IAEA/FAO Joint Divisionのような食品照射の成果に利害関係を持つ組織は除外することを求めるとともに, 特に次の事項を含む ことを要望する。 
1. WHO が以前に指摘している未解決の問題

WHO に対して，以下の問題点について事実関係を明らかにすることを要望する。

1-1．食品と接触する包装材に及ほす照射の影響（WHO Report 316，1966）

1-2．食品照射と他の処理を併用した時の栄養価に及ほす影響（WHO Report 604, 1977）

1-3. 過酸化物とエポキサイドの生成及びシスートランス異性化に係わる脂質の照射生成物の化学的, 栄養学 的, 毒性学的研究 (WHO Report 604, 1977)

1-4．タンパク質及びビタミン B 群の生物価に及ほす照射の影響（WHO Report 659, 1981）

以前にWHO のレポートでさらに検討する必要があると指摘されたこれらの問題についてのそれ以後の研究を見 いだすことができない。

2. 残留農薬, 食品添加物, 污染物質

WHO は, 残留農薬, 食品添加物, 污染物質に及ぼす照射の影響について事実関係を明らかにするとともにさ らに実施する必要のある研究を示すべきである。

これらの問題は, イギリス政府の諮問委員会により科学的データが不足していると指摘されたものである。

\section{3．動物試験において観察された好ましくない影響}

以下の照射の影響に関して肯定的あるいは否定的な結果を示しているあらゆる研究における実験デー夕と試験 方法を，WHO は総合的に評価すべきである。

免疫反応の低下

優性遺伝的損傷の増加

精子形成の減少

ポリプロイド発生の増加

新生児体重の減少

成長率の減少

腎臓障害

心臓障害

凝血能の低下

腫瘍発生率の増加

試験方法に欠陥があることが明らかになった問題点については，WHO は試験設計の欠点を明示するとともに， 論点を解決するための適切な試験方法を明らかにすべきである。 


\section{4. 照射直後の穀物}

照射後眝蔵した穀物と異なり照射直後の款物を投与すると好ましくない結果が観察されるという研究に対する 肯定的及び否定的両方のデータ及び事実関係を，WHO は特に検討すべきである。このように照射直後の款物を 用いた動物試験で悪影響が観察されるという事実を否定するための議論は事実に基づいた理屈の通った批判に対 抗できないことが明らかである。

\section{5．フリーラジカルと抗酸化性ビタミンとの反応及びビタミンの補強}

WHO は，照射によるフリーラジカル生成，ラジカル反応の停止における特定のビタミンの役割，同様のビ夕 ミンの照射による分解のしやすさ，有害な影響が観察されなかったと報告している動物試験における多量のビ夕 ミンの補強について解説すべきである。

WHO は動物試験方法の検討に際して以下のことを明らかにすべきである。

a ）食品照射に係わる動物試験における動物飼料に対するビタミン等の補強の目的は何か。

b ）その目的にとってビタミンやミネラルの補強量は適切，過鄱のいずれであったのか。

\section{6. 照射が食品の栄養価に及ぼす影響}

WHO は，照射の許可を考慮している個々の食品に及ぼす照射の影響に関する総合的なデータを提供して，線 量及び貯蔵期間を変えた時のビタミン等の栄養成分の損失の程度を明らかにするとともに, 必要ならばそのため の研究を実施すべきである。

7. 照射の管理及び乱用の防止

WHO は, 食品の微生物污染を隇少させるための放射線照射の利用に係わる公衆衛生上の問題について評価す べきである。この際，特に照射以前の污染により生成した微生物毒の残留に考虑すべきである。

WHO は以下の事項について包括的なガイドラインを作成すべきである。

a ）公采衛生当局に適した照射処理の検出技術の開発のための研究。

b ）照射食品の中の微生物毒やビールスの適切な試験のための研究。

c）適正製造規範（GMP）に係わるガイドラインが適用できるように，照射する前の食品に適用する微生物基準。

d）照射した後の食品の貯蔵と取り扱いにおける管理。

e ）食品照射の導入により現在の食品の健全性の試験法が非常に時代遅れとなった場合には，その状況に対応で きるような公衆衛生，食品管理等の担当者の教育。

\section{8. 食中毒}

WHO は食中毒の発生の程度と原因について解説するとともに, 教育, 食品や水の衛生基準, 食中毒の原因を 改善するための適切な技術に基づいて, 食中毒を防ぐための総合的な方法を開発しなければならない。食品照射 の限りある役割は, このような広い視点の中で論じなければならない。 
9. 世界的な食糧危機

WHO と FAO は協力して, 垻しい国々の依存性, 適切な財源の利用, 食品の流通や貯蔵のための適切な技術 や手段等に注意を払いながら，世界的な食糧危機，栄養失調，食品の損耗を解決するための包括的なプロジェク トを実施しなければならない。食品照射はこのような広い視点の中で論じなければならない。

(国際消費者連盟)

\section{WHO の回答}

国際消費者連盟（IOCU）のペーパー「照射食品の安全性に関する未解決の疑問」に 対するコメント

\section{著者}

D. O. Cliver

Wisconsin 大学・食品研究所及び細菌学部・教授, Madison, アメリカ

J. F. Diehl

連邦栄養研究所・教授兼所長, Karlsruhe, 西ドイッ

J. Hawthorn

Strathclyde 大学・食品科学部・名誉教授, Scotland，イギリス

E. H. Kampelmacher

農業大学・食品微生物衛生学部・名誉教授, Wageningen, オランダ

及び国立公衆衛生環境保護研究所・元副所長, Bilthoven, オランダ

$\left.\begin{array}{l}\text { 1988年12月12 16日, ジュネーブで開催された FAO/IAEA/WHO/ITC-UNCTAD/GATT 共催の照射食品の受 } \\ \text { 容，管理，貿易に関する国際会議事務局に対するWHO の Temporary Adviser }\end{array}\right)$

\section{WHO が以前に指揞している未解決の問原}

IOCU のペーパーにおいては，照射食品の安全性及び栄養性に関して未解決の問題があり，種々の WHO の報 告書でさらに研究を実施する必要がある旨指摘されていると書かれている。しかし，WHO の報告書においては， 必要な (required) 研究と好ましい (recommended または suggested) 研究とを明確に区別しており, 食品照射 に関しては，さらに実施する必要のある（required）研究は何もない。IOCU のペーパーで指摘された 4 つの問 題はすべて実施が好ましい（recommended）研究であり，これらはすべてすでに実施されている。 
1. 包装材

包装業界は種々の目的に合った新しい包装材料を常に開発している。新しく開発した包装材を放射線処理に利 用しようとする場合, その適性を適切に検討しなければならない。食品照射への利用が議論されている線量 （10kGy 以下）を照射しても，プラスチック包装資材にはほとんど影響を及ほさない。医療用具の殺菌のよう に滅菌線量を照射する場合には, 適切な包装材の選択がもっと重要になる。ある種の包装材においては照射によ りその機能性が向上するので，プラスチックや電線の製造に電離放射線が広く利用されている。

食品と接触する包装材の照射に関する多くの研究がアメリカを中心に実施されている1)。これらの研究の中に は, 包装材からの抽出物の食品への移行に関するものもある2)。アメリカ食品医薬品局（FDA）は, これらの研 究結果を注意深く評価して, 照射できる包装材の許可リストを作成し, この中には滅菌線量の放射線を照射でき るものもある ${ }^{3)}$ 。最近の FDAの食品照射に関する規則)において, FDAの作成した包装材の許可リストの正当 性を追認している。

\section{2. 照射と他の処理との併用}

照射と他の処理とを併用した時の食品の栄養価に及ほす影響については多くの研究が実施されている。これら の研究結果は1980年に開催された「食品照射における併用」に関するシンポジウム5)において議論されており, それによると, 高線量の照射により引き起こされるビタミンの損失は低温や脱酸素条件等と照射とを組み合わせ ることによりかなり防ぐことができる。

\section{3. 脂質の照射生成物}

脂質照射生成物については多くの研究が実施されている。Massachusetts 大学の W. W. Nawar は純粋な脂肪の 放射線化学に関する一連の論文を発表している6)。Nawar の研究をはじめとする種々の研究結果から, 純粋な脂 質を照射した後に起こる反応と複雑な食品の中の脂質を照射した後に起こる反応, すなわち, 実験条件下で起こ る反応と実際に食品を照射する条件下で起こる反応との間には大きな違いがあることが明らかになった7)。また， シスートランス異性化は $1000 \mathrm{kGy}$ 照射した時には観察されるが, $10 \mathrm{kGy}$ 以下の食品照射においてはあまり重要 でない(8)。

特に, 複雑な食品中の脂質は, 放射線に対する反応を起こす際に, タンパク質や抗酸化性ビタミン等の食品成 分による保護作用を受けることを理解しておくことは重要である。例えば, 純粋なニシン油を $50 \mathrm{kGy}$ 照射する と高度不飽和脂肪酸の $37 \sim 50 \%$ が分解したが，二シンの切身を $50 \mathrm{kGy}$ 照射した時には高度不飽和脂肪酸の分解 は観察されなかった ${ }^{9)}$ 。脂質の放射線による酸化がタンパク質の栄養価に及ほす影響はラットを用いて研究され ており, 脂質の不飽和化の程度及び照射中や貯蔵中の酸素の有無が栄養価に大きな影響を及ぼすことが明らかに なっている ${ }^{1011)}$ 。脂質の照射生成物の影響については Delincee ${ }^{12)}$ 及び Nawar ${ }^{13)} も$ 検討している。

\section{4. タンパク質及びビタミン B 群}

WHO Technical Report Series, №. 659 ${ }^{14)}$ はIOCU が述べているような照射食品一般ではなく, 照射した豆類の タンパク質及びビタミン B 群の生物力価についてさらに研究することを提案しており, すでに, 豆類のタンパ 
ク質やビタミン B 群に関するデータは揃えられている。インゲンマメ ${ }^{15)}$ 及びヒラマメ ${ }^{16)}$ を210kGy あるいは $180 \mathrm{kGy}$ という非常に高い線量を照射した場合，ヒナの成長率で測定したタンパク質の栄養価は少し向上する。 $10 \mathrm{kGy}$ 以下の線量を照射した場合に豆類のタンパク質の性質が改善されたり悪くなるという根拠は何もない。 ヒヨコマメ (Cajanus cajan) を10kGy 照射して未調理の状態で分析したところ,チアミンやナイアシンは $7 \%$ ， リボフラビンは 7 \%以下の損失が起こった。しかし, 照射により調理時間が短縮でき, 加熱によってもビタミン $\mathrm{B}$ 群が一部分解するので，豆を調理してから分析すると，照射試料の方が非照射試料よりもわずかにビタミン $\mathrm{B}$ 含量が高くなった ${ }^{17)}$ 。他の豆に関する研究結果は明らかでないが, ヒヨコマメの結果とそれほどは異ならない ものと思われる。

\section{残留震菜，食品添加物，污染物得}

食品中に農薬は極微量しか残留しておらず, 一般に ppm のオーダーである。食品の污染物質の問題は, 食品 加工用機械からの微量の潤滑油の混入, コンテナからの化学物質の食品への移行, PCBのような環境污染物質 の混入等多様である。食品添加物の食品中の濃度も一般に $500 \mathrm{mg} / \mathrm{kg}$ 以下と低い。

食品添加物に関しては, 最悪のケースを想定してその危険性について検討してみる。すなわち純粋な食品添加 物が $10 \mathrm{kGy}$ 照射される場合（食品添加物は実際には食品中に存在し, 食品成分による保護作用がある。，1 kg の食品添加物のうち $300 \mathrm{mg}$ が照射生成物に変換される ${ }^{18)}$ 。食品中の食品添加物の濃度が $500 \mathrm{mg} / \mathrm{kg}$ とすると, 食品 添加物の照射生成物の量は食品 $1 \mathrm{~kg}$ 当り $0.15 \mathrm{mg}$ となる。しかし, 実際には, 食品成分の保護作用により照射生成 物の漲度はさらに低くなる。

食品添加物の照射生成物の濃度は最悪の場合でも ppm のレベルであり, 農薬や食品污染物質の照射生成物の 濃度はこれょりも $2 \sim 3$ 桁低い。

このような理論的な考察以外に, 食品添加物や農薬の放射線化学については多くの実験が行われている。それ らによると, $10 \mathrm{kGy}$ 以下の線量を照射した時のこれらの化合物の分解は非常に小さく, 現在まで照射生成物と して同定されているものから判断するかぎり, 毒性学的な問題はない。

多くの植物性食品に存在する天然毒の方がはるかに大きな危険性を有しており，農薬等の照射生成物の毒性の 研究のために労力を費やすことは，実験動物の乱用及び毒性試験用試料の浪費になる。非現実的な理論的考察に よる危険性と現実とを区別することは重要である。現在食品照射が実用化されている食品に対しては, 食品添加 物はそれ程使用されていない。

\section{功物試硂において钼寨された好ましくない影需}

動物試験結果に関する包括的な評価は FAO/IAEA/WHO 照射食品の健全性に関する合同専門家委員会 (JECFI) により行われた。IOCU が要求しているようにWHOが評価をやり直しても，新しい情報は得られないであろう。 IOCU のペーパーにおいて有害な照射の影響と記されているものは, 次の 2 つの例に示すとおり, 非常に古い研 究によるものである。 


\section{心新障害}

これは，約30年前に H. Monsen により報告されたマウスを用いた実験を参考にしている。この実験の追試を

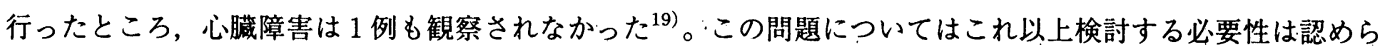
れない。

\section{㮛血能の低下}

この問題も約 30 年前に行われた研究によるものである。照射牛肉を $35 \%$ 含む飼料をラットに長期間与えたとこ ろ, 内出血が観察され，当時問題になったものである。その後の研究により，照射前の飼料のビタミン $\mathrm{K}$ 含量 が非常に低くそれを滅菌に必要な高線量照射したのでビタミン $\mathrm{K}$ がさらに隇少して, ビタミン $\mathrm{K}$ 欠乏症が現れ たものであることが明らかになった。飼料にビタミン K を添加することにより，出血は完全に防ぐことができ $た^{20) 21)}$ 。この問題についてはこれ以上検討する必要性は認められない。

\section{照射直後の稉物}

1975 1978年の期間インドの Hyderabad にある国立栄養研究所（NIN）の研究者は，照射直後の小麦をマウス， ラット，サル及び栄羑失調の子供に与えると好ましくない影響が観察され，このような影響は照射後眝蔵した小 麦では観察されないという，いくつかの論文を発表した。このことについてはJECFI，各国の政府当局や専門家 により詳しく論議され，NIN の研究結果は照射小麦に好ましくない影響があるということを表しているものでは ないという結論に達した。NIN の研究で用いられた試料数は少なくて統計的な意義が明確でなく，病理学的には 意味のあるものとは思われない。他のグループがもっと多くの試料を用いて行った追試によると, NIN の研究と 同様の結果は得られなかった（ポリプロイドについては文献22, 子宮内死亡については文献23を参照）。照射後

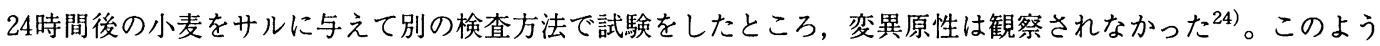
な科学的な事実以外に, 小麦を照射する目的は貯蔵することにあるという単純な事実からも, これ以上, 照射直 後の小麦に関するこの問題に係わる実験を行う必要はないと判断できる。

\section{フリーラジカルと抗䣬化性ビタミンとの反応及びビタミンの捕強}

IOCU は，毒性試験における動物飼料に対する補強の目的を明らかにするとともに，ビタミンやミネラルの補 強量が適切であったのか過剩ではなかったのかということに関する情報を提供することを要望している。高線量 照射した飼料を用いた長期間の試験においてビタミンを補強する必要性は，すでに述べたビタミン $\mathrm{K}$ 不足の例 からも明らかであろう。長期間の動物試験の目的は，試験する食品の毒性を見いだすことである。もしも動物が ビタミン不足で病気になったならば，覀い結果が得られた場合に，その原因が照射によるものかビタミン不足に よるものか判断できなくなる。長期にわたる毒性を見いだすための研究においては，試験対象の食品のビタミン 量を対照の食品のビタミン量と同じにすることが必須である。したがって，試験設計をきちんとしたものにする ために, 高線量照射した食品の試験においては, 慣例的にビタミンの補強が行われている。中線量あるいは低線 量照射した食品を試験する場合には，照射によるビタミンの損失が少ないので，ビタミンの補強の必要のないこ とが多い。ミネラルの補強は, 常に照射食品と対照食品に対して同様に行われる。 
フリーラジカルは照射食品のみに見いだされるものではなく，広く生体内で生成し，事実，人間の体内でも常 に生産されている。高濃度のフリーラジカルを含む照射食品の影響を検討するための長期の動物試験において, ラットの腫湟生成 ${ }^{25)}$ や突然変異発生 ${ }^{26)}$ に関して有害な影響は観察されなかった。

\section{照射が食品の栄誉価に及ぼす影要}

照射が食品の栄養価に及ほす影響については総説が書かれている27)。あるビタミンは照射により一部分解さ れること, 栄養成分の分解は線量の増加とともに増すが低温や脱酸素条件下で照射することにより低減できるこ とはよく知られている。このようなビタミンの損失は, 香辛料, 乾燥野菜, 穀物, バレイショ, タマネギ, 冷凍 水産物の照射等, 世界中で実施されているいかなる食品照射においても問題とはならない。好ましくない条件下 で高線量照射した時に食品によってはある種のビタミンがかなり損失するという議論は，現在実用化されている 食品照射にとっては適切ではない。食品中の栄養成分の変化を測定する高感度の方法が開発されているので，も しも現在食品照射が実用化されている食品の栄養素の損失が他の処理を施した食品よりも識別できるほど大きけ れば，照射食品の検知技術の開発という問題は解決される。

\section{照射の管理及び乱用の防止}

1 〜 10kGy の範囲の照射においてのみ照射食品の微生物に俰わることは問題となるということを認識してお く必要がある。高線量照射はWHOにより承認されていない。線量が低ければフローラに及ほす影響が小さい。 各国において刑事責任を伴う食品管理のための法律がある理由は，現在の食品保存技術が開発されるはるか昔か ら食品の供給が不適切に行われてきたことにある。ある食品の処理技術だけが他の技術と比べて不適切に利用さ れるということはない。

\section{1. 照射処理の検出技術}

照射食品の検知技術は多くの研究室で研究されており，その開発は見込みがあるように思われる。しかし，照 射により引き起こされる生化学的な変化は非常に小さく，加熱等の処理と比べてもはるかに小さいので，照射食 品の検知技術として万能な技術の開発は困難であろう。このように照射食品の万能な検知技術を開発するのが困 難な現状を考えると，食品の安全性に関するその他の多くの問題に長年係わってきた食品管理当局や食品業界に 対する国民の信頼を得ることが重要である。

\section{2. 細菌毒及びビールス}

細菌を殺滅しても食品中に毒素が残ることは事実であり，このことは加熱殺菌した牛乳において長い間問題と なっている。このような毒素を検出する試験法は開発されており，Staphylococcus aureus の場合には比較的迅速 で簡単なサーモヌクレアーゼ試験がある。照射する前の食品の細菌数を不必要に多くしないように注意すること が重要であることは明らかである。St. aureusをはじめとする毒素生産菌は, 冷蔵よりもはるかに高い温度で放 置する等の誤った取り扱いにより生育する。

食品の中に存在して人間の健康にとって重要なビールスを検出するための現在の方法はまだ多くの問題がある。 
ビールスは非常に小さいので, 食品照射によっても死滅しにくく変異も起こしにくい。しかし食品によるビール スの感染例として知られているケースは食品照射の対象となっている食品ではなく, さらに, ビールスによる食 品の污染は最終的な調理や配熷の段階で起こっている。細菌毒やビールスは食品照射に関して特に重要ではない。 食品照射の主な対象は，毎年多数の病気の原因となっている細菌の栄養細胞である。

\section{3．照射する前の食品に適用する微生物基準}

適正製造規範のための規格において，処理しようとする食品の微生物基準を定めていることがよくある。 WHO は1989年に照射する食品の微生物基準を定めるための会議を計画している。1 kGy 以下の低線量を照射す る場合にはこのような微生物基準は必要でない。

4. 照射した食品の䝪蔵と取り扱いにおける管理

照射食品の䝪蔵や取り扱いを管理するための記録の保存はすでに多くの国で実施されており，表示の問題以外 には，照射食品の管理についての問題は特にない。もしも照射食品に関する記録を保存するシステムのない国が あれば，次に述べるトレーニングコースを活用するとよい。

5. 公衆衛生, 食品管理の担当者の教育

このような目的のためのトレーニングは，オランダの国際食品照射技術施設（IFFIT）で行われている食品照 射技術のトレーニングと併行して行われている。しかし次のことは重要である。

・多くの国で既に確立している食品の管理システムは容易に照射食品の管理に適用することができる。

・食品照射の出現により現在の食品の健全性の評価技術が時代遅れになったという表現は正しくない。

・照射食品の検知技術を除いて，照射食品が他の食品とは異なる分析上の問題をもたらすことはない。

\section{食中繁}

WHO は過去35年間食中毒の程度と原因を調査しており, 多くの報告書が作成されている。これらの報告書の 多くはジュネーブにある WHO 本部で入手することができる。WHO が現在出版している文献の一覧表が最近出 された ${ }^{28)}$ 。さらに食中毒の程度や原因については世界中の多数の出版物の中にも記述されている。疫学調査に より食中毒の原因について多くのことが明らかになった。

同時に，WHO 等の国際機関，各国政府，食品業界は病原菌から食品が污染するのを制御したり防止するため

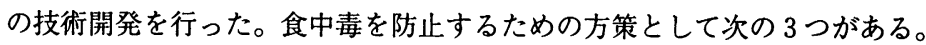

1．病原菌のいない動物の食品製造への利用

食品製造のために病原菌のいない動物を飼育することは原理的に可能であり，実験的にはすでに確立されてい る。しかし現実として病原菌のいない動物を大規模に飼育することは困難である。土壤，水，鼠，昆虫，鳥等， 環境から污染する可能性が増えているので，病原菌のいない動物を飼育することは近い将来実施できる見込みは ない。 


\section{2. 食品の処理}

食中毒を予防するための食品処理として，加熱，冷凍，乾燥，化学薬剤の使用，食品照射がある。

\section{3．情報提供と教育}

食中毒の予防のためには，消費者及び食品の流通や加工に携わる人に対する情報提供と教育が必要である。

これらの食中毒予防策のうち, 病原菌のいない動物の飼育及び情報提供と教育は現在まで食中毒の隇少に役 立っていないことを理解しておく必要がある。むしろ，多くの国において過去30４0年の間食中毒がコンスタン トに増えているのが現状であり，さらに，食中毒の原因として Campylobacter や Listeria 等の新しい微生物が見い だされている。このことは病原菌のいない動物の飼育及び情報提供や教育が不必要であるということを意味して いるのではなく，安全な食品を作出するためにはあらゆる努力を行うことが必要である。

しかし，消費者を保護するためには食品の処理が重要であることは明らかである。乳幼児，子供，免疫力の低 下した病人，入院中の患者，老人のように食品の污染に対して敏感な人にとっては，安全な食品を供給するため の食品の処理が特に重要である。食品の処理が食中毒予防に有効なことはすでに明らかであり，例えば，オラン ダでは加熱殺菌した牛乳が市場に出るようになって第二次世界大戦以後，牛乳が原因となった食中毒は発生して いない。またスコットランドでは食中毒の18\%は牛乳が原因であったが, 加熱殺菌が義務づけられてから牛乳が 原因の食中毒は隇少し，最近ではほとんどない。

家禽肉, 生の畜肉ソーセージ, エビ, カエル脚, 香辛料等の微生物污染を起こしやすい食品の殺菌は, 食中毒 の防止に役立ち, 特に, 上で述べた食品污染に敏感な人にとっては有用である。世界で食中毒の大きな原因となっ ているのが Salmonella と Campylobacterであり，これらは2.5〜 5 kGy の照射により殺滅することができる。

\section{世界的な食粞危㙨}

食料の不足や損耗が原因となる健康上及び開発上の問題は，過去40年間 WHO と FAOにより調査されており， 他の国際機関，技術関係や経済関係の機関，ボランティアグループ等も調査を行っている。食料不足や飢饉は先 進工業国よりも開発途上国において問題となる可能性があり，特に熱帯地域の国で最も急速に問題となっており， 熱帯地域では高温と高湿により食品の貯蔵が大きな問題となる。例えば，害虫や微生物による污染が原因となる 穀物や豆の損耗は20～50\%になると推定されている。

過去何十年もの間，多くの食品保存技術が開発され膨大な研究が行われたが，これらは一部の地域の食料事情 を飛躍的に改善することはあっても，全世界の食料供給を安定化させるには至っていない。このような背景を考 えると食品照射が近い将来に果たす役割は本当に小さいが，おそらく食品照射の役割は徐々に大きくなっていく であろう。

政策的には個々の特殊な事情を考察しなければならず，特に世界の最も筫しい地域においてこのようなことが 重要である。例えば，非常に筫しい地域では，利用できる資金があれば，照射施設よりも清潔な水の供給を優先 させるのが普通である。多くの人にとって非常な䝯困が意味していることを理解することは困難である。例えば, 非常に筫しい地域では，害虫の浸入を防ぐ袋等の容器がないので, 穀物は土の小屋の床の上に置かれて, 雨から 
防ぐことはできても，鼠，害虫，カビの攻撃を防止することはできない。各家庭は一回の収穫により一年分の款 物を蓄える必要があり， 5 人家族の場合には 3 トンの款物を䝪蔵する必要がある。たとえ健全な穀物を貯蔵して も，次の収穫の前の 3 ケ月の間に害虫により 20 ～ $30 \%$ 損耗するのが普通である。照射と適切な貯蔵とを組み合わ せることによって害虫による損耗を防ぐことができるが，最筫地域においては, ‘おそらく適切な袋を与えること がまず第一に行うべきことであろう。

このように, 非常に筫しい地域においては, 食品照射は食品の安定のための最初に行うべき手段ではない。食 品照射は，経済が一定の発展をしており行政，通信，サービス等の発達した地域において有効に活用できるもの である。食品照射は常に高度な技術を必要とするので対応できる行政が必要であり，照射施設は照射用試料の搬 入と照射済み試料の搬出を恒常的に安定して行う必要があるので通信が重要であり，さらに，冷蔵，エネルギー， 水等のサービスが重要である。世界のかなりの地域でまだこのような基本的な条件が揃っていない。マンゴーや パパイア等の熱帯果実の輸出を助けたり, 肉や魚等の蛋白質源のシェルライフを延長したり, 害虫による穀物や 豆の損耗を防ぐ可能性のある技術として食品照射が有効なのは，社会経済が発達した地域においてのみである。

IOCU のペーパーにおいては，FAO とWHO が飢餓等の問題を緩和するための包括的なプロジェクトを実施す るように提言しているが，これらのことこそFAO と WHO が過去40年間実施してきた活動であり，食品照射が これらの問題解決のための一つの方法（主要なものではないが）であるということをIOCU は知らないように思 われる。

\section{文献}

1. Killoran, J. J. : 「照射食品の包装」,「電離放射線による食品の保存」, Josephson and Peterson 編, CRC Press, Boca Raton, Florida, 1982/1983, Vol. 2, p.317

2. Killoran, J. J. : Radiation Research Reviews, 3， 369 (1972)

3. Federal Food, Drug and Cosmetic Act, Section 179.45

4. Federal Register 51, No.75, p.13376，1986年 4 月18日

5. Diehl, J. F. : 「照射と他の処理の併用が食品の栄養価に及ほす影響」「「食品照射における併用」, IAEA, Vienna 1981, p.349

6. Nawar, W. W. : Food Revs. Internat. 2, 45 (1986)

7. Vajdi, M. and Merritt, Jr., C. : J. Am. Oil Chem. Soc. 62, 1252 (1985)

8. Nawar, W. W. : 「食品の非水溶性成分の放射線分解」,「電離放射線による食品の保存」, Josephson and Peterson 編, CRC Press, Boca Raton, Florida, 1982/1983, Vol. 2, p.75

9. Adam, S., Paul, G. and Ehlermann, D. : Rad. Phys. Chem. 20, 289 (1982)

10. Harmuth-Hoene, A. E. and Delincee, H. : Int. J. Vitam. Nutr. Res. 48, 62 (1978)

11. Yousri, R. M. and Harmuth-Hoene, A. E. : Int. J. Vitam. Nutr. Res. 49, 171 (1979)

12. Delincee, H. : 「脂質の放射線化学の最近の進歩」,「食品照射の最近の進歩」, Elias and Cohen 編, Elsevier, Amsterdam 1983, p.89

13. Nawar, W. W. :「脂質の放射線照射と加熱処理の化学的比較」,「食品照射の最近の進歩」, Elias and Cohen 編, 
Elsevier, Amsterdam 1983, p.115

14.「照射食品の健全性」, FAO/IAEA/WHO 合同専門家委員会報告, WHO Technical Report Series, No.659, WHO, Geneva 1981

15. Reddy, S. J., Pubols, M. H. and McGinnis, J. : J. Nutrition 109, 1307 (1979)

16. Daghir, N. J., Sell, J. L. and Mateos, G. G. : Nutrit. Repts. Internat. 27, 1087 (1983)

17. Sreenivasan, A. :「いくつかの照射食品における成分と品質の変化」, 「照射による食品品質の改善」, IAEA, Vienna 1974, p.129

18.「照射食品の安全性と健全性」, 英国王室 Stationery Office, London 1986, p.17

19. Thompson, S. W., et al. : J. Nutrit. 87, 274 (1965)

20. Johnson, B. C., et al. : Fed. Proc. 19, 1038 (1960)

21. Matschiner, J. T. and Doisy, E. A. : J. Nutrit. 90, 331 (1966)

22. George, K. P. et al. : Food Cosmet. Toxicol. 14, 289 (1976)

23. Chauhan, P. S. et al. : Toxicology 7, 85 (1977)

24. Murthy, P. B. K. : Food Cosmet. Toxicol. 19, 523 (1981)

25. Renner, H. W. and Reichelt, D. : Zentralbl. Vet. Med. B20, 648 (1973)

26. Renner, H. W., Gruenewald, T. and Ehrenberg-Kieckebusch, W. : Humangenetik 18, 155 (1973)

27. Murry, T. K. :「食品照射の栄養」,「食品照射の最近の進歩」, Elias and Cohen 編, Elsevier, Amsterdam 1983, p.203

28. 食品の安全性に関する新しいWHO 出版物（WHO の非公式の書類）, 1988 